\title{
Editorial
}

\section{Molecular Endocrinology and Metabolism in 2021: What's New}

\author{
Manfredi Rizzo (1)
}

check for

updates

Citation: Rizzo, M. Molecular Endocrinology and Metabolism in 2021: What's New. Int. J. Mol. Sci. 2021, 22, 13375. https://doi.org/ $10.3390 /$ ijms 222413375

Received: 29 November 2021 Accepted: 9 December 2021 Published: 13 December 2021

Publisher's Note: MDPI stays neutral with regard to jurisdictional claims in published maps and institutional affiliations.

Copyright: (C) 2021 by the author. Licensee MDPI, Basel, Switzerland. This article is an open access article distributed under the terms and conditions of the Creative Commons Attribution (CC BY) license (https:// creativecommons.org/licenses/by/ $4.0 /)$.
School of Medicine, Department of Health Promotion, Mother and Child Care, Internal Medicine and Medical Specialties (Promise), University of Palermo, 90100 Palermo, Italy; manfredi.rizzo@unipa.it

The last two years, despite the very serious COronaVIrus Disease-2019 (COVID-19) pandemic, have been quite productive in the field of molecular endocrinology and metabolism and our journal section has contributed extensively on that. Several publications were about steroid hormones, such as estrogens and progesterone [1], and new special issues in the section "Molecular Endocrinology and Metabolism" of the International Journal of Molecular Sciences are currently accepting contributions dealing with the role of estrogen receptors in health and disease [2] and with the in vivo steroid synthesis and metabolism in healthy and pathological conditions [3]. Other authors focused on the musculoskeletal system, discussing cellular and animal models currently available for exploring skeletal muscle metabolism and endocrine function [4], and about the relationship between old age and muscle wasting in an effort to highlight the modifications in skeletal muscle metabolism associated with aging and physical activity [5].

Osteoporosis has also been a favorite topic of investigation, even with its connections to vitamin D deficiency and allergy [6,7]; in this context, a Special Issue on molecular advances in osteoporosis research still accepts valuable contributions in the section "Molecular Endocrinology and Metabolism" of the International Journal of Molecular Sciences [8]. Yet, the greatest attention has been dedicated to diabetes, insulin resistance and obesity, and their implications on cardiovascular and metabolic consequences [9-11]. It has also been emphasized that the role of lipid and glucose metabolism and chronic inflammation in the diabetes mellitus-atherosclerosis connection [12]. This is perfectly in line with the evidence that some atherogenic lipid subfractions, such as small dense low-density lipoproteins, are very closely linked to cardiovascular diseases [13], with a key role of some inflammatory cytokines, such as resistin [14].

This extensive interest over the last two years on the molecular aspects of diabetes, obesity, and their cardiometabolic consequences is not surprising, since a higher number of cardiovascular complications have been reported during the COVID-19 era [15]. In addition, it has been observed a bidirectional relationship between diabetes and COVID19: diabetes is associated with an increased risk for the most severe forms of COVID-19, hospitalization in intensive care units, and related mortality; yet, at the same time, patients with COVID-19 have shown new onset of diabetes [16-18].

This emphasizes the importance of investigating the molecular mechanisms of diabetes and other metabolic alterations, such as obesity, that can increase cardiovascular risk; new Special Issues in the section "Molecular Endocrinology and Metabolism" of the International Journal of Molecular Sciences are currently accepting contributions dealing with the mechanisms of insulin resistance and adipose tissue dysfunction [19]; obesity, genes, and obesity-related disorders [20]; the metabolic syndrome, from molecular mechanisms to novel therapies [21]; and the advances on pathophysiology and therapies of type-2 diabetes [22]. Notably, novel antidiabetic therapies glucagon-like peptide 1 receptor agonists (GLP-1 RAs), that are effective agents with significant cardiometabolic benefit [23] beyond traditional glucose-lowering drugs [24], seem to have a molecular mechanism that may interfere with COVID-19 infection and severity [25].

In summary, the section "Molecular Endocrinology and Metabolism" of the International Journal of Molecular Sciences is committed to continue to publish high-quality 
articles in the field, in order to make a significant contribution to the international scientific and medical community. There are many fields that are still awaiting to be covered, such as: (a) novel insights into physiology, pathophysiology, and therapeutics; (b) cellular interactions and factors involved; (c) cross-disciplinary and integrative studies; and (d) comparative aspects of endocrinology. We can, therefore, use this difficult COVID-19 pandemic time as an opportunity to provide the best updated scientific information and valuable novel data.

Funding: This research received no external funding.

Conflicts of Interest: Prof. Manfredi Rizzo is the Editor in Chief of the section "Molecular Endocrinology and Metabolism" of the International Journal of Molecular Sciences. The present Editorial has been prepared independently and it represents solely the personal view of the author, without any role of the publisher or the industry. No funding or writing assistance have been received.

\section{References}

1. Espinosa-Garcia, C.; Atif, F.; Yousuf, S.; Sayeed, I.; Neigh, G.N.; Stein, D.G. Progesterone Attenuates Stress-Induced NLRP3 Inflammasome Activation and Enhances Autophagy Following Ischemic Brain Injury. Int. J. Mol. Sci. 2020, 21, 3740. [CrossRef] [PubMed]

2. Available online: https://www.mdpi.com/journal/ijms/special_issues/ers3 (accessed on 28 November 2021).

3. Available online: https://www.mdpi.com/journal/ijms/special_issues/Steroid_Synthesis_Metabolism_2 (accessed on 28 November 2021).

4. Rezuş, E.; Burlui, A.; Cardoneanu, A.; Rezuş, C.; Codreanu, C.; Pârvu, M.; Rusu Zota, G.; Tamba, B.I. Inactivity and Skeletal Muscle Metabolism: A Vicious Cycle in Old Age. Int. J. Mol. Sci. 2020, 21, 592. [CrossRef] [PubMed]

5. Feraco, A.; Gorini, S.; Armani, A.; Camajani, E.; Rizzo, M.; Caprio, M. Exploring the Role of Skeletal Muscle in Insulin Resistance: Lessons from Cultured Cells to Animal Models. Int. J. Mol. Sci. 2021, 22, 9327. [CrossRef] [PubMed]

6. Sirufo, M.M.; Suppa, M.; Ginaldi, L.; De Martinis, M. Does Allergy Break Bones? Osteoporosis and Its Connection to Allergy. Int. J. Mol. Sci. 2020, 21, 712. [CrossRef] [PubMed]

7. De Martinis, M.; Allegra, A.; Sirufo, M.M.; Tonacci, A.; Pioggia, G.; Raggiunti, M.; Ginaldi, L.; Gangemi, S. Vitamin D Deficiency, Osteoporosis and Effect on Autoimmune Diseases and Hematopoiesis: A Review. Int. J. Mol. Sci. 2021, 22, 8855. [CrossRef] [PubMed]

8. Available online: https://www.mdpi.com/journal/ijms/special_issues/osteoporosis2 (accessed on 28 November 2021).

9. Galicia-Garcia, U.; Benito-Vicente, A.; Jebari, S.; Larrea-Sebal, A.; Siddiqi, H.; Uribe, K.B.; Ostolaza, H.; Martín, C. Pathophysiology of Type 2 Diabetes Mellitus. Int. J. Mol. Sci. 2020, 21, 6275. [CrossRef] [PubMed]

10. Hong, S.-H.; Choi, K.M. Sarcopenic Obesity, Insulin Resistance, and Their Implications in Cardiovascular and Metabolic Consequences. Int. J. Mol. Sci. 2020, 21, 494. [CrossRef] [PubMed]

11. Martinelli, I.; Tomassoni, D.; Moruzzi, M.; Roy, P.; Cifani, C.; Amenta, F.; Tayebati, S.K. Cardiovascular Changes Related to Metabolic Syndrome: Evidence in Obese Zucker Rats. Int. J. Mol. Sci. 2020, 21, 2035. [CrossRef] [PubMed]

12. Poznyak, A.; Grechko, A.V.; Poggio, P.; Myasoedova, V.A.; Alfieri, V.; Orekhov, A.N. The Diabetes Mellitus-Atherosclerosis Connection: The Role of Lipid and Glucose Metabolism and Chronic Inflammation. Int. J. Mol. Sci. 2020, 21, 1835. [CrossRef] [PubMed]

13. Rizzo, M.; Berneis, K. Who needs to care about small, dense low-density lipoproteins? Int. J. Clin. Pract. 2007, 61, 1949-1956. [CrossRef] [PubMed]

14. Abate, N.; Sallam, H.S.; Rizzo, M.; Nikolic, D.; Obradovic, M.; Bjelogrlic, P.; Isenovic, E.R. Resistin: An inflammatory cytokine. Role in cardiovascular diseases, diabetes and the metabolic syndrome. Curr. Pharm. Des. 2014, 20, 4961-4969. [CrossRef] [PubMed]

15. Saeed, S.; Tadic, M.; Larsen, T.H.; Grassi, G.; Mancia, G. Coronavirus disease 2019 and cardiovascular complications: Focused clinical review. J. Hypertens. 2021, 39, 1282-1292. [CrossRef] [PubMed]

16. Stoian, A.P.; Banerjee, Y.; Rizvi, A.A.; Rizzo, M. Diabetes and the COVID-19 Pandemic: How Insights from Recent Experience Might Guide Future Management. Metab. Syndr. Relat. Disord. 2020, 18, 173-175. [CrossRef] [PubMed]

17. Bornstein, S.R.; Rubino, F.; Ludwig, B.; Rietzsch, H.; Schwarz, P.E.H.; Rodionov, R.N.; Khunti, K.; Hopkins, D.; Birkenfeld, A.L.; Boehm, B.; et al. Consequences of the COVID-19 pandemic for patients with metabolic diseases. Nat. Metab. 2021, 3, $289-292$. [CrossRef] [PubMed]

18. Ceriello, A.; Stoian, A.P.; Rizzo, M. COVID-19 and diabetes management: What should be considered? Diabetes Res. Clin. Pract. 2020, 163, 108151. [CrossRef] [PubMed]

19. Available online: https://www.mdpi.com/journal/ijms/special_issues/IR_ATD (accessed on 28 November 2021).

20. Available online: https://www.mdpi.com/journal/ijms/special_issues/obesity_genes (accessed on 28 November 2021).

21. Available online: https://www.mdpi.com/journal/ijms/special_issues/MS_IJMS (accessed on 28 November 2021).

22. Available online: https://www.mdpi.com/journal/ijms/special_issues/t2d (accessed on 28 November 2021). 
23. Rizzo, M.; Nikolic, D.; Patti, A.M.; Mannina, C.; Montalto, G.; McAdams, B.S.; Rizvi, A.A.; Cosentino, F. GLP-1 receptor agonists and reduction of cardiometabolic risk: Potential underlying mechanisms. Biochim. Biophys. Acta Mol. Basis Dis. 2018, 1864, 2814-2821. [CrossRef] [PubMed]

24. Berneis, K.; Rizzo, M.; Stettler, C.; Chappuis, B.; Braun, M.; Diem, P.; Christ, E.R. Comparative effects of rosiglitazone and pioglitazone on fasting and postprandial low-density lipoprotein size and subclasses in patients with Type 2 diabetes. Expert Opin. Pharmacother. 2008, 9, 343-349. [CrossRef] [PubMed]

25. Banerjee, Y.; Pantea Stoian, A.; Silva-Nunes, J.; Sonmez, A.; Rizvi, A.A.; Janez, A.; Rizzo, M. The role of GLP-1 receptor agonists during COVID-19 pandemia: A hypothetical molecular mechanism. Expert Opin. Drug Saf. 2021, 20, 1309-1315. [CrossRef] [PubMed] 